\title{
Debriefing methods and techniques used in nursing simulation
}

\author{
Métodos e técnicas de debriefing utilizados em simulação na enfermagem \\ Métodos y técnicas de debriefing utilizadas en la simulación de enfermería
}

How to cite this article: Nascimento JSG, Oliveira JLG, Alves MG, Braga FTMM, Góes FSN, Dalri MCB. Debriefing methods and techniques used in nursing simulation. Rev Gaúcha Enferm. 2020;41:e20190182. doi: https://doi. org/10.1590/1983-1447.2020.20190182 a Universidade de São Paulo (USP). Escola de Enfermagem de Ribeirão Preto. Ribeirão Preto, São Paulo, Brasil.

- Universidade do Estado de Minas Gerais (UEMG). Passos, Minas Gerais, Brasil.

\section{Juliana da Silva Garcia Nascimento ${ }^{a}$ Jordana Luiza Gouvêa de Oliveira ${ }^{a}$ Mateus Goulart Alves ${ }^{\mathrm{b}}$ \\ Fernanda Titareli Merizio Martins Braga ${ }^{a}$ Fernanda dos Santos Nogueira de Góes ${ }^{\mathrm{a}}$ Maria Celia Barcellos Dalria}

\section{ABSTRACT}

Objective: To identify in the literature methods and techniques of debriefing used in teaching and learning in nursing simulation. Methods: Integrative review of PubMed/MEDLINE ${ }^{\circledast}$, LILACS, Scopus and CINAHL ${ }^{\oplus}$ databases, with the descriptors" "nursing", "nursing education", respective terms in English and Spanish, and the keyword "debriefing". Twelve primary studies, in Portuguese, English and Spanish, from January 2008 to December 2018 were included. Qualitative analysis was used to categorize the domains.

Results: The identified meaningful learning methods were based on principles of transfer of learning; model of clinical reasoning, interprofessional, with good judgment and structured and self-debriefing techniques, oral, eye-tracking, video-assisted and written debriefing.

Conclusions: The structured method and the oral technique with video were outstanding. One method was not superior to the other but effective for a particular proposal. No national studies have been found. Research should be conducted on the effectiveness of nursing debriefing methods and techniques.

Keywords: Nursing. Education, nursing. Debriefing. Educational technology. Simulation.

\section{RESUMO}

Objetivo: Identificar na literatura métodos e técnicas de debriefing utilizados no processo de ensino e aprendizagem na simulação em enfermagem.

Métodos: Revisão integrativa, nas bases de dados PubMed/MEDLINE ${ }^{\circledR}$, LLLACS, Scopus e CINAHL ${ }^{\circledR}$, com os descritores "enfermagem", "educação em enfermagem", respectivos termos em inglês e espanhol e a palavra chave "debriefing" Incluíram-se 12 estudos primários, nos idiomas português, inglês e espanhol, de janeiro de 2008 a dezembro de 2018. Utilizou-se análise qualitativa para categorização dos domínios.

Resultados: Identificaram-se os métodos de debriefing Meaningful Learning; based on principles of transfer of learning; model of clinical reasoning, interprofissional, com bom julgamento e estruturado, e técnicas self-debriefing; oral; Eye-Tracking; videoassistido e written debriefing.

Conclusões: Sobressaíram-se o método estruturado e a técnica oral com vídeo. Um método não foi superior ao outro, mas eficaz para determinada proposta. Não foram encontrados estudos nacionais. Sugere-se, pesquisas sobre a eficácia dos métodos e técnicas debriefing na enfermagem.

Palavras-chave: Enfermagem. Educação em enfermagem. Debriefing. Tecnologia educacional. Simulação.

\section{RESUMEN}

Objetivo: Identificar en la literatura los métodos y técnicas de análisis utilizados en el proceso de enseñanza y aprendizaje en la simulación de enfermería.

Métodos: Revisión integradora en las bases de datos PubMed/MEDLINE ${ }^{\oplus}$, LLLACS, Scopus y CINAHL ${ }^{\oplus}$, con los descriptores "enfermería", "educación de enfermería", términos respectivos en inglés y español y la palabra clave "interrogatorio". Doce estudios primarios en portugués, inglés y español, desde enero de 2008 hasta diciembre de 2018. Se utilizó el análisis cualitativo para clasificar los dominios. Resultados: Se identificaron los métodos de análisis significativo de información; Basado en principios de transferencia de aprendizaje; modelo de razonamiento clínico, interprofesional, bien juzgado y estructurado, y técnicas de autoinforme; oral Seguimiento de los ojos; Video asistido y redacción de informes.

Conclusiones: Se destaca el método estructurado y la técnica oral con video. Un método no era superior a otro, pero era efectivo para una propuesta dada. No se encontraron estudios nacionales. Se sugiere, investigación sobre la efectividad de los métodos y técnicas de interrogatorio en enfermería.

Palabras clave: Enfermería. Educación en enfermería. Interrogatorio. Tecnología educacional. Simulación. 


\section{口 INTRODUCTION}

The increasing complexity of health systems and greater awareness of user rights have forced nurses to adapt to this scenario ${ }^{(1)}$. Simulation in initial and continuing nursing education to support teaching and learning is currently considered one of the best ways to improve the capacity to reflect and reason clinically and develop competencies ${ }^{(2)}$.

Simulation is an active teaching and learning strategy whereby students actively participate in scenarios that mimic real-life situations and consequently engage in reflective practices, divided into three phases, namely preparation, participation and debriefing ${ }^{(2-4)}$.

The preparation phase is further divided into pre-simulation, which addresses the supply of teaching resources for the proposed theme, and pre-briefing or briefing, an introductory phase, which precedes the scenario and contains simulation guidelines for the participants ${ }^{(4)}$. The participation phase, also called "scenario", comprises the practice experience ${ }^{(4)}$. Debriefing is an analytical process of reflection that occurs after or during the simulation scenario to develop knowledge, skills and attitudes in the people involved ${ }^{(5-8)}$. Moreover, debriefing is responsible for about $80 \%$ of the learning acquired by participants in a simulation, making it invaluable for education ${ }^{(9)}$.

Several terms are identified in the literature to describe the elements of debriefing, including method, model, process, phases, sections, parts, components, steps, techniques, strategies, styles, types, approaches, characteristics and considerations. These terms are used interchangeably, which hinders the determination of a precise language that clarifies what one intends to study ${ }^{(10)}$. Thus, with the intent of standardizing the terminology and eliminating possible conceptual confusion, the term "method" is used here to name the adopted debriefing structure and the word "technique" is used to define the way debriefing is enabled ${ }^{(10)}$.

More than 30 methods and 10 debriefing techniques have emerged in the last decade. However, there is still a shortage of well-outlined studies on nursing education using this process, thus creating a knowledge gap on the most effective debriefing method and technique for this purpose $\mathrm{e}^{(1,10-13)}$. To ensure the development of competence using simulations in nursing with rigor and excellence, it is imperative that the professional responsible for debriefing have the consistency and scientific basis to choose and conduct the preferred method and technique ${ }^{(11-14) .}$ Consequently, it is fundamental to encourage discussion on debriefing methods and techniques used for simulation in nursing.
Thus, the objective of this integrative review is to identify in the literature debriefing methods and techniques used for teaching and learning in nursing simulation.

\section{METHODS}

This is an integrative literature review within the scope of nursing simulation on debriefing methods and techniques employed in the teaching and learning process.

The steps of the integrative review were selection of the review question, definition of the sample, definition of the primary research characteristics, analysis of the findings, interpretation of the results and reproduction of the review ${ }^{(15)}$.

The searches were carried out from May to July 2018 using the PICO (patient, intervention, comparison, outcomes) strategy ${ }^{(16)}$, to describe the following elements: "P" referred to students and nursing professionals; "I" referred to application of the debriefing methods and techniques; " $\mathrm{C}$ "was not applied in this review and "O" $\mathrm{O}$ "referred to nursing education. The research question was the following: What scientific evidence is available in the literature regarding debriefing methods and techniques that enable nursing education? The following databases were consulted: PubMed/MEDLINE Literatura Latino-Americana e do Caribe em Ciências da Saúde (LILACS), Scopus and Cumulative Index to Nursing and Allied Health Literature (CINAHL). Descriptors and keywords were used to conduct the studies search. The health sciences descriptors (DeCS) were "enfermagem" and "educação em enfermagem" in addition to their English language equivalents - "nursing" and "nursing education" - in the Medical Subjects Headings (MESH). The term "debriefing" was used as a keyword to increase specificity on the theme during the search. Two independent researchers simultaneously conducted the search in the selected databases using the same combination of terms. Chart 1 describes the search strategies used in the databases.

We included primary studies that responded the question regarding debriefing methods and techniques that enable nursing education published from January 2008 to December 2018 - a temporal profile justified by an emphasis on transformational pedagogical practices established in the national curriculum guidelines of the referred period ${ }^{(17)}$. Articles published in Portuguese, English and Spanish in scientific journals and available electronically were considered for the review. Literature reviews, editorials, overviews, experience reports, case studies, theoretical reflections, dissertations, theses, monographs and abstracts published in annals of events were excluded. 


\begin{tabular}{|l|l|}
\hline Data analysis & Strategy \\
\hline PubMed/MEDLINE' & $\begin{array}{l}\text { Debriefing AND (Nursing OR Nursings) AND ("Education, Nursing" OR "Nursing Education" OR } \\
\text { "Educations, Nursing" OR "Nursing Educations") }\end{array}$ \\
\hline SCOPUS & $\begin{array}{l}\text { Debriefing AND (Nursing OR Nursings) AND "Education, Nursing" OR "Nursing Education" OR } \\
\text { "Educations, Nursing" OR "Nursing Educations" }\end{array}$ \\
\hline CINAHL & Debriefing AND Nursing AND "Education, Nursing" \\
\hline LILACS & $\begin{array}{l}\text { Debriefing AND (Nursing OR Enfermagem OR Enfermería) AND ("Education, Nursing" OR } \\
\text { "Educação em Enfermagem" OR "Educación, Enfermería") }\end{array}$ \\
\hline Web of Science & $\begin{array}{l}\text { Debriefing AND (Nursing OR Nursings) AND ("Education, Nursing" OR "Nursing Education" OR } \\
\text { "Educations, Nursing" OR "Nursing Educations") }\end{array}$ \\
\hline
\end{tabular}

Chart 1 - Search strategies used in the databases selected for the study

Source: Authors.

CINAHL: Cumulative Index to Nursing and Allied Health Literature; LILACS: Literatura Latino-Americana e do Caribe em Ciências da Saúde.

Data were collected using the instrument proposed by Ursi and Galvão(18), as follows: identification of the article (title, study number, authors, level of evidence, place and year of publication), methodological design, and information on the presented debriefing methods and techniques. The proposal of Melnyk et al. ${ }^{(19)}$ was used to classify the level of evidence of the studies. Two reviewers independently assessed the studies and any disagreements were forwarded to a third reviewer who specializes in the field to reach an agreement. The bibliographical reference manager EndNote Basic was used to organize the records found in the searches ${ }^{(20)}$. The path of study selection was presented in the flowchart proposed in the Preferred Reporting Items for Systematic Reviews and Meta-Analyses (PRISMA) (21) (Figure 1).

In the descriptive analysis, the articles were read in full and the findings were categorized into two domains, namely debriefing methods, addressing the structural models used in nursing, and debriefing techniques, focusing on the strategies that enable the process. The largest number of studies was identified in the PubMed database, configuring 479 articles, followed by the Scopus base, with 401 studies. In the CINAHL database, 312 articles were found, in LILACS,6, and in the Web of Science, 5 articles were found.

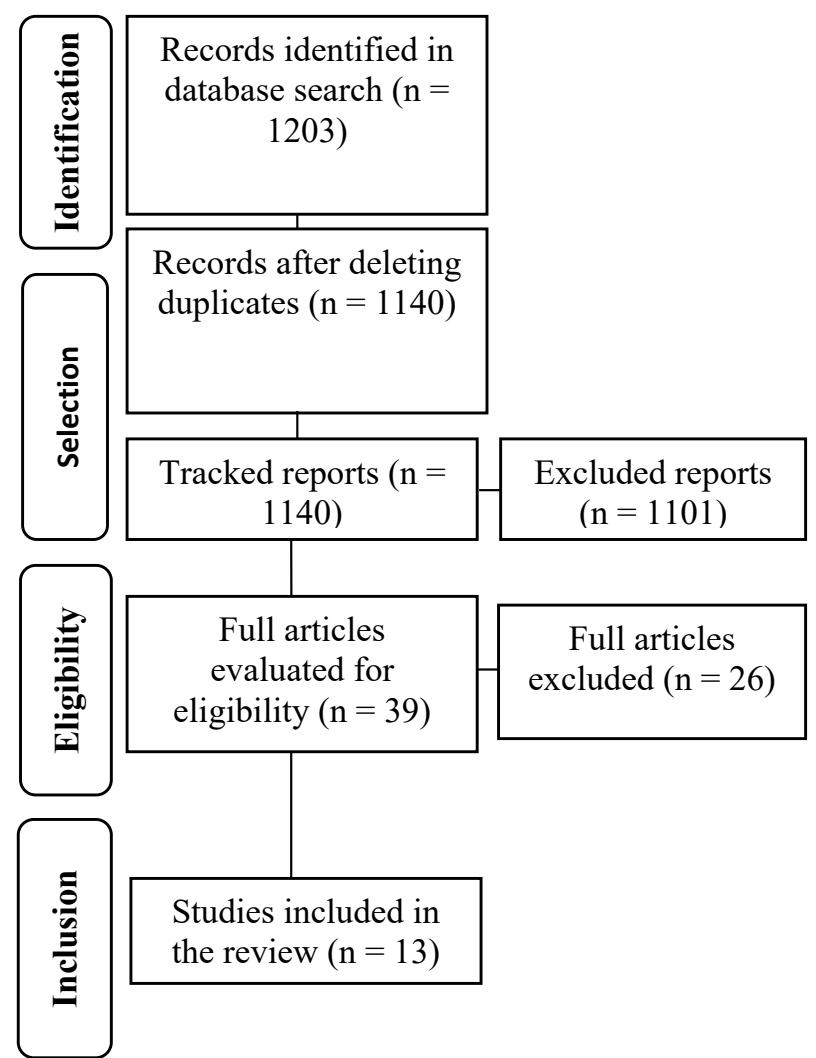

Figure 1 - Flowchart of the process of identification, selection and inclusion of studies, as recommended in PRISMA. Source: Search data, 2018, based on Moher et al. ${ }^{(21)}$ 


\section{RESULTS}

Thirteen primary studies were eligible for the final sample of this review. Charts 2 to 4 show the authors of the studies included in the review, country of origin of the study, classification of the level of evidence, design of the studies, methods and techniques of debriefing used in the nursing simulation and its lead authors.

\begin{tabular}{|c|c|c|}
\hline Authors & Country & Level of evidence \\
\hline Kang et al. ${ }^{(1)}$ & South Korea & III \\
\hline Reed $^{(12)}$ & USA & $\|$ \\
\hline Dreifuerst ${ }^{(22)}$ & USA & III \\
\hline Johnston et al..(23) & Australia & $\|$ \\
\hline Kuiper et al. (24) & USA & $\mathrm{VI}$ \\
\hline Poore et al. ${ }^{(25)}$ & USA & $\mathrm{VI}$ \\
\hline Reierson et al..(26) & Norway & V \\
\hline Mariani et al.(27) & USA & V \\
\hline Mariani et al. ${ }^{(28)}$ & USA & III \\
\hline Grant et al. ${ }^{(29)}$ & USA & $\|$ \\
\hline$H a^{(30)}$ & South Korea & $\mathrm{VI}$ \\
\hline Henneman et al. ${ }^{(31)}$ & USA & ॥ \\
\hline Maestre et al. ${ }^{(32)}$ & Spain & V \\
\hline
\end{tabular}

Chart 2 - Selected studies, country of origin and classification of the level of evidence Source: Research data, 2018.

\begin{tabular}{|l|l|l|}
\hline Authors & Outline & Debriefing method and lead authors \\
\hline Johnston et al. ${ }^{(23)}$ & $\begin{array}{l}\text { Pilot study, randomized clinical, controlled } \\
\text { with mixed approach, which tested de- } \\
\text { briefing using the principles of learning } \\
\text { transfer theory }\end{array}$ & $\begin{array}{l}\text { Debriefing based on principles of transfer } \\
\text { of learning } \\
\text { Lead author: Salomon et al. }{ }^{\left({ }^{34)}\right.}\end{array}$ \\
\hline Kuiper et al. ${ }^{(24)}$ & $\begin{array}{l}\text { Descriptive study reporting experiences with } \\
\text { nursing students and comparing their ability } \\
\text { to develop clinical reasoning supported } \\
\text { by debriefing }\end{array}$ & $\begin{array}{l}\text { Debriefing using the OPT model of } \\
\text { clinical reasoning } \\
\text { Lead author: Kuiper et al. }{ }^{(24)}\end{array}$ \\
\hline Poore et al. ${ }^{(25)}$ & $\begin{array}{l}\text { Methodological study, validation and appli- } \\
\text { cation of debriefing tool }\end{array}$ & $\begin{array}{l}\text { Interprofessional debriefing } \\
\text { (DIPRR) } \\
\text { Lead author: Poore et al. }{ }^{(25)}\end{array}$ \\
\hline Reierson et al. ${ }^{(26)}$ & $\begin{array}{l}\text { Exploratory qualitative study conducted with } \\
\text { nursing students, with traditional oral de- } \\
\text { briefing and structured debriefing associated } \\
\text { with video recording }\end{array}$ & $\begin{array}{l}\text { Structured debriefing } \\
\text { Lead authors: Fanning et al. }{ }^{(35)} \\
\text { and Phrampus et al. }{ }^{(36)}\end{array}$ \\
\hline Mariani et al..$^{(27)}$ & $\begin{array}{l}\text { A descriptive, qualitative pilot study on } \\
\text { structured debriefing }\end{array}$ & $\begin{array}{l}\text { Structured debriefing } \\
\text { Lead authors: Fanning et al. }{ }^{(35),} \\
\text { Phrampus et al. }{ }^{(36)}\end{array}$ \\
\hline
\end{tabular}

Chart 3 - Outlines and debriefing method identified in the articles, with their respective leading authors 


\begin{tabular}{|c|c|c|}
\hline Authors & Outline & Debriefing method and lead authors \\
\hline Mariani et al. ${ }^{(28)}$ & $\begin{array}{l}\text { Mixed method quasi-experimental study } \\
\text { with structured debriefing }\end{array}$ & $\begin{array}{l}\text { Structured debriefing } \\
\text { Lead authors: Fanning et al. }{ }^{(35)} \\
\text { and Phrampus et al. } .^{(36)}\end{array}$ \\
\hline Maestre and Rudolph ${ }^{(32)}$ & $\begin{array}{l}\text { Descriptive study, with a qualitative ap- } \\
\text { proach, on the principles of debriefing with } \\
\text { good judgment }\end{array}$ & $\begin{array}{l}\text { Debriefing with good judgment } \\
\text { Lead author: Maestre et al. }{ }^{(32)}\end{array}$ \\
\hline Dreifuerst ${ }^{(33)}$ & $\begin{array}{l}\text { Quasi-experimental study, with pre-test and } \\
\text { post-test application to investigate the de- } \\
\text { velopment of clinical reasoning in students } \\
\text { through debriefing }\end{array}$ & $\begin{array}{l}\text { Debriefing for Meaningful Learning } \odot \\
\text { Lead author: Dreifuerst }{ }^{(33)}\end{array}$ \\
\hline
\end{tabular}

\section{Chart 3 - Cont.}

Source: Research data, 2018.

OPT: Outcome Present State-Test Model. DIPRR: Debriefing Interprofessionally: Recognition \& Reflection.

\begin{tabular}{|c|c|c|}
\hline Authors & Outline & Debriefing techniques and lead authors \\
\hline $\begin{array}{l}\text { Kang } \\
\text { et al. }{ }^{(1)}\end{array}$ & $\begin{array}{l}\text { Quasi-experimental study comparing } \\
\text { debriefing techniques }\end{array}$ & $\begin{array}{l}\text { Auto-debriefing (self-debriefing) technique } \\
\text { Unknown author } \\
\text { Oral debriefing technique alone } \\
\text { Lead author: Fanning et al. }{ }^{(35)}\end{array}$ \\
\hline Reed $^{(12)}$ & $\begin{array}{l}\text { Experimental study comparing stu- } \\
\text { dent experiences applying three } \\
\text { debriefing techniques }\end{array}$ & $\begin{array}{l}\text { Oral debriefing technique alone } \\
\text { Lead author: Fanning et al. }{ }^{(35)} \\
\text { Oral debriefing technique associated with written de- } \\
\text { briefing recorded in a blog or collaborative debriefing } \\
\text { Lead author: Petranek }{ }^{(37)} \\
\text { Oral debriefing technique associated with written de- } \\
\text { briefing recorded in journal or journaling } \\
\text { Lead author: Petranek }{ }^{(37)}\end{array}$ \\
\hline $\begin{array}{l}\text { Grant } \\
\text { et al. }{ }^{(29)}\end{array}$ & $\begin{array}{l}\text { Study based on the Q methodology, which } \\
\text { integrated quantitative and qualitative } \\
\text { methods to identify perception in relation } \\
\text { to the applied debriefing technique }\end{array}$ & $\begin{array}{l}\text { Video-assisted debriefing technique } \\
\text { Lead author: Grant et al.(29) } \\
\text { Levett-Jones et al..(38) }\end{array}$ \\
\hline$H a^{(30)}$ & $\begin{array}{l}\text { Quasi-experimental study comparing the } \\
\text { oral debriefing technique associated with } \\
\text { oral debriefing video alone }\end{array}$ & $\begin{array}{l}\text { Oral debriefing technique alone } \\
\text { Lead author: Fanning et al..(35) } \\
\text { Video-assisted debriefing technique } \\
\text { Lead author: Grant et al.(29) }\end{array}$ \\
\hline $\begin{array}{l}\text { Henneman } \\
\text { et al. }{ }^{(31)}\end{array}$ & $\begin{array}{l}\text { Experimental study with pre-and post-test } \\
\text { application to compare the efficacy of three } \\
\text { debriefing techniques and determine the } \\
\text { most effective }\end{array}$ & $\begin{array}{l}\text { Oral debriefing techniques alone } \\
\text { Lead author: Fanning et al. }{ }^{(35)} \\
\text { Eye-tracking debriefing technique alone } \\
\text { Lead author: Fisher et al.(.39) } \\
\text { Oral debriefing technique combined with eye-tracking } \\
\text { Lead author: Fisher et al..(39) }\end{array}$ \\
\hline
\end{tabular}

Chart 4 - Outlines and debriefing techniques identified in the articles, with their respective lead authors 


\section{DISCUSSION}

The low number of studies that composed this review reveals that research on the most appropriate debriefing methods and techniques for nursing simulation may still be in the early stages. The main methods identified were meaningful learning debriefing; debriefing based on principles of transfer of learning; debriefing model of clinical reasoning and interprofessional debriefing, debriefing with good judgment and structured debriefing.

Meaningful learning debriefing uses "Socratic questioning" whereby the teacher does not directly answer students' questions but responds with a series of questionings that allow students to decide on the best answer, triggering reflection on the clinical practice ${ }^{(33)}$.

Debriefing based on principles of transfer of learning addresses the ability to generalize the skills learned and project them into real experiences, thus allowing students to use past experiences or future situations to make meaningful the scenarios proposed in the simulation ${ }^{(23)}$.

The debriefing method model of clinical reasoning (OPT) promotes reflection among students through the comparison of the patient's current clinical status and the desired clinical status and focuses on identifying and assessing nursing diagnoses ${ }^{(24)}$.

Interprofessional debriefing, on the other hand, is used in nursing to address teamwork in a way that values knowledge, skills and attitudes in a multiprofessional context of work and the competency of collaboration ${ }^{(25)}$. The debriefing method with good judgment specifies a process of reflection that helps students solve clinical and behavioral dilemmas raised by simulation through self-reflection and behavioral change ${ }^{(33)}$.

It was noted, however, that the structured debriefing method is commonly used in teaching and learning in nursing, chiefly based on two styles of structured reflection: three-phase structures, composed of debriefing divided into 3 distinct phases and multiphasic structures, consisting of more than three phases for reflection ${ }^{(40)}$.

In nursing, the three-phase debriefing structures are more common than the multiphasic structures ${ }^{(40)}$, corroborating the findings of this review, in which three-phase debriefing models were also identified. The most commonly used three-phase structured debriefing model was developed by Rudolph et al., characterized by the steps of reaction, analysis and synthesis ${ }^{(8,40)}$, which were identified in this review. In this structured debriefing model, the reaction phase allows participants to release emotions and tensions, the analysis phase addresses the exposure of events, discussion and articulation with the literature and the synthesis phase consists of reviewing the lessons learning and presenting the objectives, positive aspects and points of improvement $\mathrm{t}^{(3,38,41)}$.

The need to express emotions and remain calm during the reaction phase is fundamental for learning to occur in the simulation since this process causes anxiety and stress in the participants and clouds their judgment and reasoning ability ${ }^{(42)}$.

The phases of analysis and synthesis, in turn, promote reflection, which is crucial in learning because it modifies behaviors due to the acquired knowledge and interpretation of the experienced situations ${ }^{(43)}$. Studies have identified that nursing students who participate in structured debriefing and synthesize all the components of a simulated experience in a context they consider meaningful(2,26) find it easier to reflect assertively and comprehensively ${ }^{(24)}$, develop critical thinking and the ability to integrate new information and improve their clinical judgment ability ${ }^{(26)}$. Today, the body of evidence that evaluates debriefing methods is increasing although a given method is usually chosen according to the personal preference of the facilitator without regard for the context and the objectives ${ }^{(4)}$. Regardless of the preferred debriefing style, conducting a phase-organized reflection session with clear and precise learning objectives is an extremely difficult task for the mediator teacher due to the challenge of dealing with the unexpected, converting difficulties into achievements and achieving meaningful learning ${ }^{(44-45)}$.

Because simulations have a variety of contexts and objectives, the educational value and impact of debriefing depend on this intentionality, and specific methods can be useful in a proposed situation, indicating that one method is not superior to the other but only more effective to achieve a given goal ${ }^{(46)}$.

With regard to exploring the most common debriefing techniques for nursing simulations, the identified techniques were self-debriefing; eye-tracking debriefing; written debriefing; oral debriefing and video-assisted debriefing.

In self-debriefing, participants debrief without the help of a facilitator or instructor ${ }^{(35)}$. A more complex technique than self-debriefing is eye tracking, which consists of ocular tracking technology that captures the participants' movements during the simulated scene and highlights behavior that guides and facilitates debriefing ${ }^{(39)}$. In the written debriefing technique, participants use an electronic device to write descriptions of their observations and reports, among other topics, on a blog, individually or jointly ${ }^{(37)}$. 
Emphasis was given on oral debriefing associated with the video-assisted debriefing. Two studies, conducted with nursing students ${ }^{(47)}$ and health workers ${ }^{(48)}$ did not identify statistically significant differences between the two techniques regarding the performance of those involved, suggesting nursing educators can use either technique to achieve learning outcomes in the simulation ${ }^{(46)}$.

A study addressing such techniques, conducted with nursing students to determine the effects of debriefing technique on the reduction of psychophysiological stress of participants in a simulation, did not find a significant difference for such responses ${ }^{(49)}$.

An integrative review of the best available scientific evidence regarding video-assisted debriefing compared to the oral debriefing technique found 14 studies involving the subject ${ }^{(50)}$ and the authors concluded that the results of these publications are highly heterogeneous regarding the efficacy of video-assisted debriefing. Moreover, the level of evidence of the publications suggests the elaboration of more consistent studies related to the debriefing structure, to the study design and to the description of randomization ${ }^{(49)}$. Therefore, further scientific research should be conducted regarding the efficacy of video-assisted debriefing, which is often cited as the gold standard compared to oral debriefing, with the configuration of empiricism as to the evidence of educational benefits when associating both techniques ${ }^{(50)}$. The incipient results without statistical significance in most of the included studies were considered a limitation in this study, although almost all the studies had representative samples of their populations and revealed other characteristics, such as the satisfaction of participants with the methods or techniques addressed.

\section{- CONCLUSION}

The main debriefing methods used for teaching and learning in nursing are meaningful learning, based on transfer of learning principles, using the outcome-present state-test, interprofessional, with good judgment and structured. The most frequently used debriefing techniques were oral, oral associated with video-assisted, with eye-tracking, writing and self-debriefing. Of these techniques, structured debriefing and the association of the oral technique and video-assisted debriefing were highlighted. One method was not superior to the other, but more effective in achieving a given proposal. This integrative review contributed to teaching, research and care in nursing by synthesizing knowledge regarding debriefing methods and techniques with a focus on simulation and by facilitating the choice of professors in nursing and nurses regarding the best practices for planning and conducting debriefing. We did not find Brazilian studies that tested debriefing methods and techniques. Consequently, further studies should be conducted to compare the efficacy of debriefing methods and techniques in nursing simulation and explore new approaches.

\section{口REERENCES}

1. Kang K, Yu M. Comparison of student self-debriefing versus instructor debriefing in nursing simulation: a quasi-experimental study. Nurse Educ Today. 2018;2:67-73. doi: https://doi.org/10.1016/j.nedt.2018.02.030

2. Garner SL, Killingsworth E, Bradshaw M, Raj L, Jhonson SR, Abijah SP, et al. The impact of simulation education on self-efficacy towards teaching for nurse educators. Int Nurs Rev. 2018;65(4):586-595. doi: https://doi.org/10.1111/ inr. 12455

3. Cant RP, Cooper SJ. Use of simulation-based learning in undergraduate nurse education: an umbrella systematic review. Nurse Educ Today. 2017;49:63-71. doi: https://doi.org/10.1016/j.nedt.2016.11.015

4. Tyerman J, Luctkar-Flude M, Graham L, Coffey S, Olsen-Lynch E. A systematic review of health care presimulation preparation and briefing effectiveness. Clin Simul Nurs. 2019;27:12-25. doi: https://doi.org/10.1016/j.ecns.2018.11.002

5. Cuerva MJ, Piñel CS, Martin L, Espinosa JA, Corral 0J, Mendoza N. Teaching childbirth with high-fidelity simulation. Is it better observing the scenario during the briefing session? J Obstet Gynaecol. 2018;38(5):607-10. doi: https:// doi.org/10.1080/01443615.2017.1393403

6. AI Sabei SD, Lasater K. Simulation debriefing for clinical judgment development: a concept analysis. Nurse Educ Today. 2016;45:42-7. doi: https://doi. org/10.1016/j.nedt.2016.06.008

7. Gardner R. Introduction to debriefing. Semin Perinatol. 2013;37(3):166-74. do: https://doi.org/10.1053/.semperi.2013.02.008

8. Rudolph JW, Simon R, Raemer DB, Eppich WJ. Debriefing as formative assessment: closing performance gaps in medical education. Acad Emerg Med. 2008;15(11):1010-6. doi: https://doi.org/10.1111/j.15532712.2008.00248.x

9. Abatzis VT, Littlewood KE. Debriefing in simulation and beyond. Int Anesthesiol Clin. 2015;53(4):151-62. doi: https://doi.org/10.1097/AlA. 0000000000000070

10. Waznonis AR. Methods and evaluations for simulation debriefing in nursing education. I Nurs Educ. 2014;53(8):459-65. doi: https://doi. org/10.3928/01484834-20140722-13

11. Coyne E, Rands H, Frommolt V, Kain V, Plugge M, Mitchell M. Investigation of blended learning video resources to teach health students clinical skills: an integrative review. Nurse Educ Today. 2018;63:101-7. doi: https://doi.org/ 10.1016/j.nedt.2018.01.021

12. Reed SJ. Written debriefing: evaluating the impact of the addition of a written component when debriefing simulations. Nurse Educ Pract. 2015;15(6):543-8. doi: https://doi.org/10.1016/j.nepr.2015.07.011

13. Dufrene C, Young A. Successful debriefing - best methods to achieve positive learning outcomes: a literature review. Nurse Educ Today. 2014;34(3):372-6. doi: https://doi.org/10.1016/j.nedt.2013.06.026 
14. Danski MT, Oliveira GL, Pedrolo E, Lind J, Johann DA. Importance of evidencebased practice in nurse's work process. Cienc Cuid Saude. 2017;16(2):e36304. doi: https://doi.org/10.4025/cienccuidsaude.v16i2.36304

15. Ganong LH. Integrative reviews of nursing research. Res Nurs Health. 1987,10(1):1-11. doi: https://doi.org/10.1002/nur.4770100103

16. Santos CM, Pimenta CA, Nobre MR. The PICO strategy for the research question construction andevidencesearch. RevLatino-Am Enfermagem. 2007;15(3):50811. doi: https://doi.org/10.1590/S0104-11692007000300023

17. Souza EF, Silva AG, Silva AL. Active methodologies for graduation in nursing: focus on the health care of older adults. Rev Bras Enferm. 2018;71(2):976-80. doi: https://doi.org/10.1590/0034-7167-2017-0150

18. Ursi ES, Galvão CM. Prevenção de lesões de pele no perioperatório: revisão integrativa da literatura. Rev Latino-Am Enfermagem. 2006;14(1):124-31. doi: https://doi.org/10.1590/S0104-11692006000100017

19. Melnyk BM, Fineout-Overholt E. Evidence-based practice in nursing \& healthcare: a guide to best practice. 2. ed. Philadelphia: Wolters Kluwer Health/ Lippincott Williams \& Wilkins; 2011

20. Estorniolo Filho J. ENDNOTE basic: guia de uso. 12a atual. São Paulo: Biblioteca Centro de Informação e Referência, Faculdade de Saúde Pública, USP; 2018 [cited 2018 Dec 15]. Available from: http://www.biblioteca.fsp.usp.br/wpcontent/uploads/2018/03/EndNote_basic_12.pdf

21. Moher D, Liberati A, Tetzlaff J, Altman DG, PRISMA Group. Preferred reporting items for systematic reviews and meta-analyses: the PRISMA statement. Int J Surg. 2010;8(5):336-41. doi: https://doi.org/10.1016/j.ijsu.2010.02.007

22. Dreifuerst KT. Getting started with debriefing for meaningful learning using debriefing for meaningful learning to foster development of clinical reasoning in simulation. J Nurs Educ. 2012;51(6):326-33. doi: https://doi. org/10.3928/01484834-20120409-02

23. Johnston S, Coyer F, Nash R. Simulation debriefing based on principles of transfer of learning: a pilot study. Nurse Educ Pract. 2017;26:102-8. doi: https:// doi.org/10.1016/j.nepr.2017.08.002

24. Kuiper RN, Heinrichy C, Matthias A, Graham MJ, Bell-Kotwallyy L. Debriefing with the OPT model of clinical reasoning during high fidelity patient simulation. Int J Nurs Educ Scholarsh. 2008;5:Article 17. doi: https://doi.org/10.2202/1548923X.1466

25. Poore JA, Dawson JC, Dunbar DM, Parrish K. Debriefing interprofessionally: a tool for recognition and reflection. Nurse Educ. 2019;44(1):25-8. doi: https:// doi.org/10.1097/NNE.0000000000000518

26. Reierson IÅ, Haukedal TA, Hedeman H, Bjørk IT. Structured debriefing: what difference does it make? Nurse Educ Pract. 2017;25:104-10. doi: https://doi. org/10.1016/j.nepr.2017.04.013

27. Mariani B, Cantrell MA, Meakim C. Nurse educators'perceptions about structured debriefing in clinical simulation. Nurs Educ Perspect. 2014;35(5):330-1. doi: https://doi.org/10.5480/13-1190.1

28. Mariani B, Cantrell MA, Meakim C, Prieto P, Dreifuerst KT. Structured debriefing and students' clinical judgment abilities in simulation. Clin Simul Nurs. 2013;9(5):e147-55. doi: https://doi.org/10.1016/j.ecns.2011.11.009

29. Grant JS, Dawkins D, Molhook L, Keltner NL, Vance DE. Comparing the effectiveness of video-assisted oral debriefing and oral debriefing alone on behaviors by undergraduate nursing students during high-fidelity Simulation. Nurse Educ Pract. 2014;14(5):479-84. doi: https://doi.org/10.1016/j. nepr.2014.05.003
30. Ha EH. Attitudes toward Video-Assisted Debriefing after simulation in undergraduate nursing students: an application of Q methodology. Nurse Educ Today. 2014;34(6):978-84. doi: https://doi.org/10.1016/j.nedt.2014.01.003

31. Henneman EA, Cunningham H, Fisher DL, Plotkin K, Nathanson BH, Roche JP, et al. Eye tracking as a debriefing mechanism in the simulated setting improves patient safety practices. Dimens Crit Care Nurse. 2014;33(3):129-35. doi: https://doi.org/10.1097/DCC.0000000000000041

32. Rudolph J.W, Maestrea JM. Teorías y estilos de debriefing: el método con buen juicio como herramienta de evaluación formativa en salud. Rev Esp Cardiol. 2015;68(4):282-5. doi: https://doi.org/10.1016/j.recesp.2014.05.018

33. Dreifuerst KT. Getting started with debriefing for meaningful learning. Clin Simul Nurs. 2015;11(5):268-75. doi: https://doi.org/10.1016/j.ecns.2015.01.005

34. Salomon G, Perkins DN. Rocky roads to transfer: rethinking mechanism of a neglected phenomenon. Educ Psychol. 2010;24(2):113-42. doi: https://doi. org/10.1207/s15326985ep2402_

35. Fanning RM, Gabba DM. The role of debriefing in simulation-based learning. Simul Healthc. 2007:2(2):115-25. doi: https://doi.org/10.1097/ SIH.0b013e3180315539

36. Phrampus PE, O'Donnell JM. Healthcare simulation: from 'best secret' to 'best practice'. In: Levine Al, DeMaria Jr S, Schwartz AD, Sim A. Comprehensive textbook of healthcare simulation. New York: Springer; 2013. p. 73-84.

37. Petranek (F. Written debriefing: the next vital step in learning with simulations. Simul Gam. 2000;31(1):108-18. doi: https://doi.org/10.1177/ 104687810003100111

38. Levett-Jones T, Lapkin S. A systematic review of the effectiveness of simulation 372 debriefing in health professional education. Nurse Educ Today. 2014;34(6):e58-63. doi: https://doi.org/10.1016/j.nedt.2013.09.020

39. Fisher DL, Wisher RA, Ranney T. Optimal static and dynamic training schedules: state models of skill acquisition. J Math Psychol. 1996;40(1):30-47. doi: https:// doi.org/10.1006/jmps.1996.0002

40. Sawyer T, Eppich W, Brett-Fleegler M, Grant V, Cheng A. More than one way to debrief a critical review of Healthcare Simulation Debriefing Method. Simul Healthc. 2016;11(3):209-17. doi: https://doi.org/10.1097/ SIH.0000000000000148

41. Rudolph J, Simon R, Dufresne R, Raemer D. There's no such thing as "nonjudgmental" debriefing: a theory and method for debriefing with good judgment. Simul Healthc. 2006;1(1):49-55. doi: https://doi.org/ 10.1097/01266021-200600110-00006

42. Palaganas JC, Fey MN, Simon R. Structured debriefing in simulation-based education. AACN Adv CritCare. 2016;27(1):78-85. doi: https://doi.org/10.4037/ aacnacc2016328

43. Li N, Li B, Dou J, Wang X. The anxiety and influence factor of the nurse students in different levels before the NCLEX-RN. Iran J Public Health. 2015 [cited 2019 Apr 20];44(4):588-9. Available from: https://www.ncbi.n/m.nih.gov/pmc/ articles/PMC4441974/

44. McGonagle I, Jackson CS, Kane R. The ten essential shared capabilities: reflections on education in values based practice: a qualitative study. Nurse Educ Today. 2015;35(2):e24-e28. doi: https://doi.org/10.1016/j. nedt.2014.12.001 
45. Ali L, Nisar S, Ghassan A. Role of debriefing as a learning tool in simulation based learning for students of preclinical years at the end of two consecutive modules-initial experience. J Ayub Med Coll Abbottabad. 2015 [cited 2019 Apr 10];27(2):425-9. Available from: https://jamc.ayubmed.edu.pk/index.php/ jamc/article/view/66/45

46. Cheng A, Dieckmann P, Arora S, Robinson T, Eppich W. Faculty development for simulation programs five issues for the future of debriefing training. Simul Healthc. 2015;10(4):217-22. doi: https://doi.org/10.1097/SIH.000 0000000000090

47. Grant JS, Dawkins D, Molhook L, Keltner NL, Vance DE. Comparing the effectiveness of video-assisted oral debriefing and oral debriefing alone on behaviors by undergraduate nursing students during high-fidelity simulation. Nurse Educ Pract. 2014;14(5):479-84. doi: https://doi.org/10.1016/j. nepr.2014.05.003
48. Niemants J, Hanchard B, Gerard V, Horlait G. Comparing effectiveness of videoassisted oral debriefing versus oral debriefing alone during human resuscitation simulation: a randomized trial. Ressuscitation. 2016;106(Suppl 1):87. doi: https://doi.org/10.1016/j.resuscitation.2016.07.209

49. Rossignol M. Effects of video-assisted debriefing compared with standard oral debriefing. Clinic Simul Nurs. 2017;13(4):145-53. doi: https://doi.org/ 10.1016/j.ecns.2016.12.001

50. Ali AA, Miller ET. Effectiveness of video-assisted debriefing in health education: an integrative review. J Nurs Educ. 2018;57(1):14-20. doi: https://doi.org/ 10.3928/01484834-20180102-04

\section{- Corresponding author:}

Juliana da Silva Garcia Nascimento

E-mail: mestradounesp28@yahoo.com.br

\section{Associate editors:}

Juliana Petri Tavares

Graziella Badin Aliti

Editor-in-chief:

Approved: 08.27.2019
Maria da Graça Oliveira Crossetti 